\title{
Nicole de Margival, Le dit de la panthère
}

\section{G. Matteo Roccati}

\section{(2) OpenEdition}

\section{Journals}

\section{Édition électronique}

URL : https://journals.openedition.org/studifrancesi/38957

DOI : $10.4000 /$ studifrancesi.38957

ISSN : 2427-5856

\section{Éditeur}

Rosenberg \& Sellier

\section{Édition imprimée}

Date de publication : 1 décembre 2004

Pagination : 334

ISSN : 0039-2944

\section{Référence électronique}

G. Matteo Roccati, « Nicole de Margival, Le dit de la panthère », Studi Francesi [En ligne], 143 (XLVIII | II) | 2004, mis en ligne le 30 novembre 2015, consulté le 19 mai 2021. URL : http://

journals.openedition.org/studifrancesi/38957 ; DOI : https://doi.org/10.4000/studifrancesi.38957

Ce document a été généré automatiquement le 19 mai 2021.

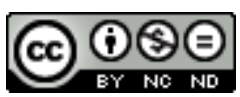

Studi Francesi è distribuita con Licenza Creative Commons Attribuzione - Non commerciale - Non opere derivate 4.0 Internazionale. 


\title{
Nicole de Margival, Le dit de la panthère
}

\author{
G. Matteo Roccati
}

\section{RÉFÉRENCE}

NICOLE DE MARGIVAL, Le dit de la panthère, édité par Bernard RIBÉMONT, Paris, Honoré Champion Éditeur («Les Classiques Français du Moyen Age», 136), 2000, pp. 154.

1 L'introduction (pp. 9-42) présente les deux manuscrits contenant le dit et les questions relatives au titre, à la paternité et à la date de l'oeuvre. Suivent l'étude de la langue du manuscrit de base (BNF, fr. 24432), un résumé et une analyse littéraire du texte, ainsi que des repères bibliographiques. On trouvera après l'édition les notes (où apparaissent aussi les leçons rejetées), les variantes, le glossaire et l'index des noms propres et des figures allégoriques. 